\title{
New screening system for simultaneous determination of two marker proteins by homogeneous enzyme immunoassay
}

\author{
N Hoshino, K Miyai
}

\begin{abstract}
Aims: To save time and labour in mass screening, by detecting two marker proteins on one specimen using only one test.

Methods: $\alpha$ Fetoprotein and ferritin were chosen to demonstrate the principal of this system. The assay reagents were horseradish peroxidase (HRP)-labelled anti- $\alpha$ fetoprotein and HRP-labelled antiferritin antibodies. After the serum sample had been incubated with these reagents the substrate for HRP was added and the absorbance measured. An absorbance value below the cutoff point indicated that both parameters were within normal limits; a value above the cutoff point indicated that at least one of the two parameters was abnormally high. Results: Fifty sera from healthy Japanese subjects were assayed by the simultaneous assay method. All samples gave absorbancy values below the cutoff point. Fifty serum samples from patients with high $\alpha$ fetoprotein concentrations (over $20 \mathrm{ng} / \mathrm{ml}$ ) and 50 samples with high ferritin concentrations (over $200 \mathrm{ng} / \mathrm{ml}$ ) were also assayed. The absorbancy values of all samples with high $\alpha$ fetoprotein concentrations, and all but one sample with high ferritin concentrations gave values above the cutoff point.

Conclusions: Although this homogeneous enzyme assay method was applied to the combination of $\alpha$ fetoprotein and ferritin, it could be used in mass screening for any other combination of two markers.
\end{abstract}

Interest has recently focused on the diagnosis and treatment of various concomitant diseases in the same patient. It is imperative that subclinical conditions should be detected before they become manifest. Mass screening to detect subclinical conditions in large populations therefore offers considerable promise.

Most diagnostic methods are designed to measure one disease parameter in individual patients by one test on individual samples in vitro. But this would require very large numbers of assays for mass screening, so a more suitable screening method is needed.

We developed a mass screening system that could determine two parameters at once using $\alpha$ fetoprotein and ferritin concentrations determined by homogeneous enzyme immunoassay as a model system.

\section{Methods}

Horseradish peroxidase, grade I.C, RZ 3.1, was purchased from Toyobo Co., Japan. The $\mathrm{N}$-hydroxysuccinimide ester of $\mathrm{N}$-(4-carboxycyclohexylmethyl)-maleimide (CHM) was from Zieben Chemical Co., Japan. Sephadex G-25 and Sephacryl S-200 came from Pharmacia Fine Chemicals, Sweden. Other reagents were obtained from Wako, Japan.

Rabbit anti- $\alpha$ fetoprotein and anti-ferritin were prepared from serum samples of rabbits immunised with $\alpha$ fetoprotein and ferritin, respectively, in complete Freund's adjuvant. Antibodies were isolated by immunoaffinity chromatography, and $F\left(a^{\prime}\right)_{2}$ fragments were prepared by digestion of the antibodies with pepsin. ${ }^{1}$

Enzyme-labelled antibodies were prepared, as described previously. ${ }^{2}$ The carbohydrate moiety of HRP was oxidised by treating the enzyme with sodium periodate $\left(\mathrm{NaIO}_{4}\right)$ using the method of Nakane and Kawaoi. ${ }^{3} \mathrm{~A}$ mixture of $2 \mathrm{ml}$ of HRP treated with sodium periodate $(5 \mathrm{mg} / \mathrm{ml})$ in $1 \mathrm{mM}$ sodium acetate buffer $(\mathrm{pH}$ 4.2 ) and $2 \mathrm{ml}$ of $0.3 \mathrm{M} \mathrm{NaHCO}$ containing $60 \mathrm{mM}$ tetramethylenediamine was incubated for two hours at $25^{\circ} \mathrm{C}$ with continuous stirring to allow for the formation of the Shiff base. Then $0.1 \mathrm{ml}$ of freshly prepared $\mathrm{NaBH}_{4}$ solution $(4 \mathrm{mg} / \mathrm{ml})$ was added to reduce the Shiff base. The mixture was left to stand for one hour at $4^{\circ} \mathrm{C}$, dialysed against $20 \mathrm{mM}$ sodium phosphate buffered saline, $\mathrm{pH} 7 \cdot 0$ (PBS), and then subjected to gel filtration on a Sephacryl S-200 column $(2.5 \times 90 \mathrm{~cm})$ equilibrated with PBS. Fractions containing monomer HRP (44000) were collected. Then $3 \mathrm{mg} / \mathrm{ml}$ of the monomer HRP, introduced with an amino group in $2 \mathrm{ml}$ of $50 \mathrm{mM}$ phosphate buffer $(\mathrm{pH} \mathrm{7.0)}$, was mixed with $22 \mathrm{mM} \mathrm{CHM}$ in dioxane $(0 \cdot 1 \mathrm{ml})$. After incubation for one hour at $25^{\circ} \mathrm{C}$ the reaction mixture was filtered through a Sephadex G-25 column $(1.5 \times 15 \mathrm{~cm})$ equilibrated with $50 \mathrm{mM}$ phosphate buffer (pH 7.0) and fractions containing the protein (maleimide conjugated HRP) were pooled.

A sample of $2 \mathrm{ml}$ of purified $\mathrm{F}\left(\mathrm{ab}^{\prime}\right)_{2}$ fragment of anti-human $\alpha$ fetonrotein antibody or antiferritin antibody $(5 \mathrm{mg} / \mathrm{ml})$ in $50 \mathrm{mM}$ sodium acetate buffer (pH 5.0 ) was mixed with $0.1 \mathrm{ml}$ of $0.25 \mathrm{M} 2$-mercaptoethylamine and was left to stand at $37^{\circ} \mathrm{C}$ for 90 minutes. The mixture was then applied to a Sephadex G-25 column $(1.5 \times 15 \mathrm{~cm})$ equilibrated with $50 \mathrm{mM}$ phosphate buffer ( $\mathrm{pH} 7 \cdot 0)$ and fractions of 
eluate containing the Fab' fragment were pooled. A volume of $2 \mathrm{ml}$ of maleimide conjugated HRP $(2 \mathrm{mg} / \mathrm{ml})$ was added to $3 \mathrm{ml}$ of Fab' fragment of anti-human $\alpha$ fetoprotein or anti-ferritin antibody $(8 \mathrm{mg})$ prepared as described above. The mixture was shaken continuously for one hour at $25^{\circ} \mathrm{C}$, left to stand at room temperature for 16 hours, and then applied to a Sephacryl S-200 column $(2.5 \times$ $90 \mathrm{~cm}$ ) equilibrated with PBS. The first major peak of material eluted from the column was collected. The HRP in this fraction carried two to four fragments of anti-human $\alpha$ fetoprotein antibody or anti-ferritin antibody.

STANDARD PROCEDURE FOR HOMOGENEOUS ENZYME IMMUNOASSAY FOR $\alpha$ FETOPROTEIN AND FERRITIN

A mixture of $50 \mu \mathrm{l}$ of test serum and $100 \mu \mathrm{l}$ of HRP-labelled antibodies in PBS containing $3 \%$ polyethylene glycol 6000 (PEG) was incubated for 20 minutes at $37^{\circ} \mathrm{C}$. Then $0.5 \mathrm{~m}$ of PBS containing $25 \mathrm{mM}$ phenol, $0.75 \mathrm{mM}$ 4-aminoantipyrine, and $35 \mathrm{mM}$ hydrogen peroxide was added. After incubation for 10 minutes at $37^{\circ} \mathrm{C} 2 \mathrm{ml}$ of $1.8 \%$ formaldehyde in PBS was added to stop the enzyme reaction and the absorbance was measured at $500 \mathrm{~nm}$ (As). As a control, the procedure was carried out with HRP-labelled normal IgG instead of HRP-labelled antibody and the absorbancy was determined $\left(A_{0}\right)$. The HRP activity of the test sample was expressed as $A=A S-A_{0}$. Under these conditions HRP-labelled antibody has no catalytic activity, but HRP labelled antibody aggregates (bound with antigen) show catalytic activity.

\section{Results}

CALIBRATION CURVES FOR ASSAYS OF $\alpha$ FETOPROTEIN AND FERRITIN BY ORDINARY HOMOGENEOUS EIA

Calibration curves for $\alpha$ fetoprotein and ferritin were made using WHO standards diluted with PBS containing $4.5 \%$ bovine serum albumin.

Figure 1 Calibration curves for measurements of $\alpha$ fetoprotein and ferritin by ordinary homogeneous EIA.

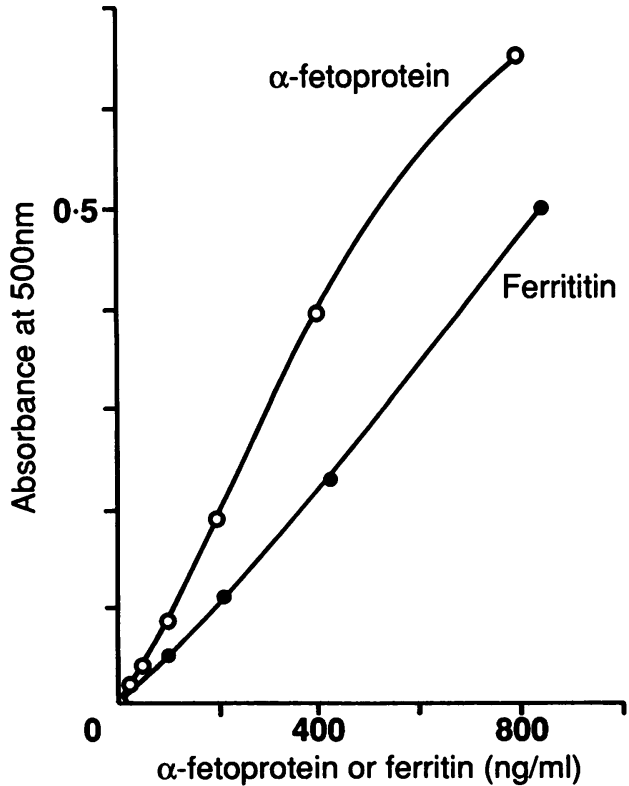

$\alpha$ Fetoprotein and ferritin at concentrations of $10-800 \mathrm{ng} / \mathrm{ml}$ were determined quantitatively (fig 1).

SIMULTANEOUS ASSAY OF $\alpha$ FETOPROTEIN

The cutoff values of $\alpha$ fetoprotein and ferritin were set at $20 \mathrm{ng} / \mathrm{ml}$ and $200 \mathrm{ng} / \mathrm{ml}$, respectively. To reduce the contribution of ferritin to the optical density, unlabelled anti-ferritin antibody was added to the assay mixture. As shown in fig $2240 \mu \mathrm{g} / \mathrm{ml}$ of anti-ferritin antibody was required to adjust the absorbance of $200 \mathrm{ng} / \mathrm{ml}$ ferritin to that of $20 \mathrm{ng} / \mathrm{ml} \alpha$ fetoprotein.

The assay mixture for simultaneous determination of $\alpha$ fetoprotein and ferritin was as follows: $100 \mu \mathrm{l}$ of reagent containing $3 \%$ PEG, $1 \mu \mathrm{g} / \mathrm{ml}$ of HRP-labelled anti- $\alpha$ fetoprotein, $1 \mu \mathrm{g} / \mathrm{ml}$ of anti-ferritin antibodies and $240 \mu \mathrm{g} / \mathrm{ml}$ of unlabelled anti-ferritin in PBS were admixed with $50 \mu$ l of sample solution. After incubating the mixture for 20 minutes at $37^{\circ} \mathrm{C}$ enzyme activity was measured.

\section{ASSESSMENT OF SIMULTANEOUS ASSAY}

Dose-response curve

Typical dose-response curves in this assay

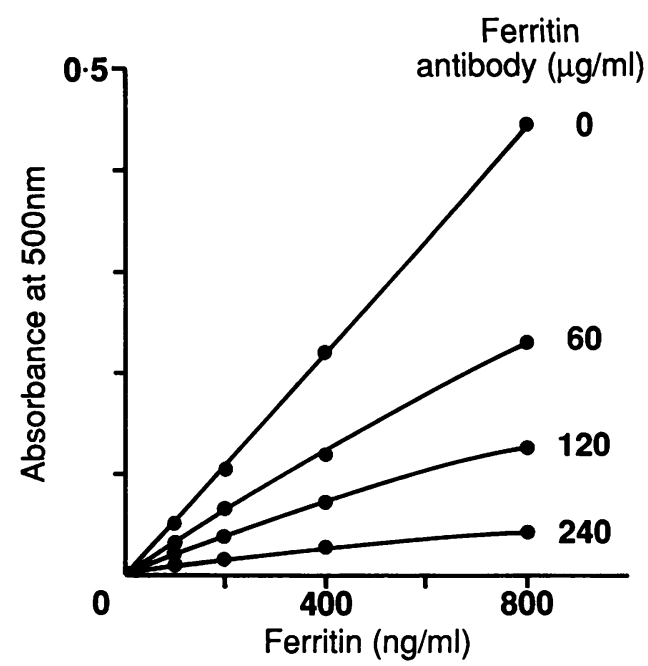

Figure 2 Effect of addition of unlabelled anti-ferritin antibody to the assay mixture.

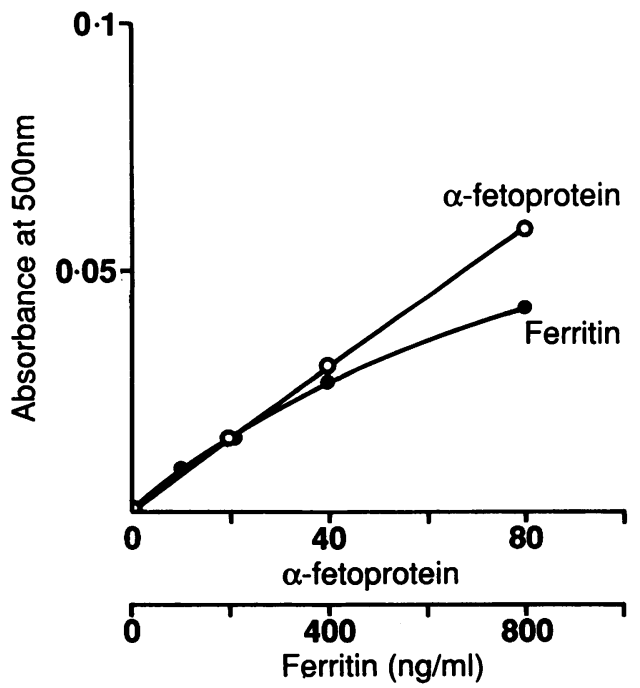

Figure 3 Dose-response curves of $\alpha$ fetoprotein and ferritin in the simultaneous assay. 
Figure 4 Relation between the concentrations of $\alpha$ fetoprotein and ferritin and their absorbancies in mixed samples.

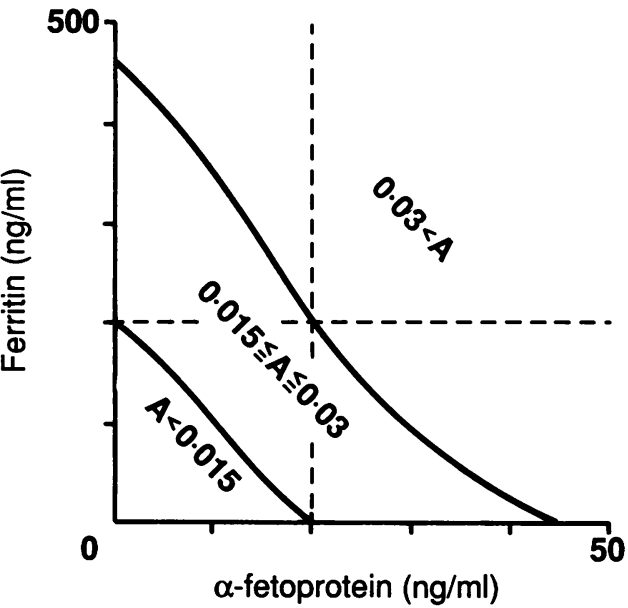

procedure using $\alpha$ fetoprotein and ferritin separately are shown in fig 3 . The relation between the absorbancy and the concentrations of $\alpha$ fetoprotein and ferritin in mixed samples is shown in fig 4. Criteria for evaluation of tests were deduced from these data (table 1). Samples giving an absorbancy of under 0.015 were evaluated as negative (the concentrations of both $\alpha$ fetoprotein and ferritin being below the cutoff point); those with absorbancies of over 0.030 were evaluated as positive (the concentrations of $\alpha$ fetoprotein or ferritin being above

Table 1 Criteria for evaluating results of the simultaneous assay

\begin{tabular}{|c|c|c|c|}
\hline $\begin{array}{l}\text { Absorbancy } \\
(A)\end{array}$ & $\begin{array}{l}\text { Concentrations of } A F P \text { and ferritin } \\
(\mathrm{ng} / \mathrm{ml})\end{array}$ & $\begin{array}{l}\text { Evaluation for } \\
\text { screening }\end{array}$ & $\begin{array}{l}\text { Confirmatory } \\
\text { examination }\end{array}$ \\
\hline$A<0.015$ & AFP $<20$ and ferritin $<200$ & Negative & Negative \\
\hline $\begin{array}{l}0.015 \leqq \mathrm{~A} \\
\leqq 0.030\end{array}$ & $\left.\begin{array}{l}\text { AFP }<20 \text { and ferritin }<200 \\
\text { AFP }>20 \text { or ferritin }>200\end{array}\right\}$ & Suspicious & \multirow{2}{*}{$\begin{array}{l}\text { Determine } \\
\text { AFP and } \\
\text { ferritin } \\
\text { separately }\end{array}$} \\
\hline $0.030<\mathrm{A}$ & AFP $>20$ and/or ferritin $>200$ & Positive & \\
\hline
\end{tabular}

AFP $=\alpha$-fetoprotein.

Table 2 Precision of assay

\begin{tabular}{|c|c|c|c|c|}
\hline \multirow{2}{*}{$\begin{array}{l}\alpha-f \text { etoprotein standard } \\
(\mathrm{n}=10)\end{array}$} & \multicolumn{2}{|l|}{ Intra-assay } & \multicolumn{2}{|l|}{ Inter-assay } \\
\hline & $\operatorname{Mean}(S D)(m A)$ & $C V(\%)$ & $\operatorname{Mean}(S D)(m A)$ & $C V(\%)$ \\
\hline $\begin{array}{l}20 \mathrm{ng} / \mathrm{ml} \\
40 \mathrm{ng} / \mathrm{ml} \\
80 \mathrm{ng} / \mathrm{ml}\end{array}$ & $\begin{array}{l}15 \cdot 3(0.95) \\
29.7(1.77) \\
56 \cdot 2(2 \cdot 30) \\
\text { Average }\end{array}$ & $\begin{array}{l}6 \cdot 2 \\
5 \cdot 9 \\
4 \cdot 1 \\
5 \cdot 4\end{array}$ & $\begin{array}{l}15 \cdot 5(1 \cdot 58) \\
29 \cdot 4(2 \cdot 22) \\
57 \cdot 7(2 \cdot 67)\end{array}$ & $\begin{array}{r}10 \cdot 2 \\
7 \cdot 6 \\
4 \cdot 6 \\
7 \cdot 5\end{array}$ \\
\hline $\begin{array}{l}\text { Ferritin standard }(\mathrm{n}=10) \\
200 \mathrm{ng} / \mathrm{ml} \\
400 \mathrm{ng} / \mathrm{ml} \\
800 \mathrm{ng} / \mathrm{ml}\end{array}$ & $\begin{array}{l}14.7(0.95) \\
27.4(2.01) \\
41.2(1.48) \\
\text { Average }\end{array}$ & $\begin{array}{l}6 \cdot 5 \\
7 \cdot 3 \\
3 \cdot 6 \\
5 \cdot 8\end{array}$ & $\begin{array}{l}15.0(1.33) \\
26.7(2.21) \\
41.3(1.89)\end{array}$ & $\begin{array}{l}8 \cdot 9 \\
8 \cdot 3 \\
4 \cdot 6 \\
7 \cdot 3\end{array}$ \\
\hline
\end{tabular}

$\mathrm{mA}=$ milliabsorbance.

Table 3 Evaluation of samples supplemented with $\alpha$-fetoprotein or ferritin by simultaneous assay

\begin{tabular}{|c|c|c|c|}
\hline $\begin{array}{l}\alpha-f e t o p r o t e i n \text { concentration } \\
\text { added }(\mathrm{ng} / \mathrm{ml})\end{array}$ & $\begin{array}{l}\text { Observed absorbance } \\
(m A)\end{array}$ & $\begin{array}{l}\text { Determined concentration } \\
(\mathrm{ng} / \mathrm{ml})\end{array}$ & Evaluation * \\
\hline $\begin{array}{r}0 \\
20 \\
50 \\
100\end{array}$ & $\begin{array}{r}9 \\
21 \\
40 \\
65\end{array}$ & $\begin{array}{l}\overline{28} \\
54 \\
94\end{array}$ & $\begin{array}{l}\text { Negative } \\
\text { Suspicious } \\
\text { Positive } \\
\text { Positive }\end{array}$ \\
\hline $\begin{array}{l}\text { Ferritin concentration }(\mathrm{ng} / \mathrm{ml}) \\
0 \\
200 \\
400 \\
600\end{array}$ & $\begin{array}{r}9 \\
22 \\
33 \\
38\end{array}$ & $\begin{array}{l}3 \overline{10} \\
560 \\
700\end{array}$ & $\begin{array}{l}\text { Negative } \\
\text { Suspicious } \\
\text { Positive } \\
\text { Positive }\end{array}$ \\
\hline
\end{tabular}

The original sample was pooled normal human serum with an $\alpha$-fetoprotein concentration of

$4 \mathrm{ng} / \mathrm{ml}$ and a ferritin concentration of $132 \mathrm{ng} / \mathrm{ml}$ (measured by usual assays).
$\star$ Determined by simultaneous assay using the calibration curves shown in fig 3 . the cutoff point); those with values of between 0.015 and 0.030 were evaluated as suspicious (the concentration of either $\alpha$ fetoprotein or ferritin possibly being above the cutoff point). When values were positive or suspicious, $\alpha$ fetoprotein and ferritin were measured separately to determine which parameter was increased.

\section{Precision}

The intra-assay and interassay coefficients of variation $(\mathrm{CVs})$ were examined by 10 replicate determinations by simultaneous assay method on samples containing either $20 \mathrm{ng}, 40 \mathrm{ng}$, or $100 \mathrm{ng} / \mathrm{ml}$ of $\alpha$ fetoprotein, or $200 \mathrm{ng}, 400 \mathrm{ng}$, or $800 \mathrm{ng} / \mathrm{ml}$ of ferritin. The average intraassay CVs were 5.4 and $5.8 \%$ and the average interassay CVs were $7 \cdot 5$ and $7 \cdot 3 \%$, respectively (table 2).

\section{Analysis of samples supplemented with authentic} $\alpha$ fetoprotein and ferritin

Pooled normal human sera ( $\alpha$ fetoprotein $4 \mathrm{ng} / \mathrm{ml}$; ferritin $132 \mathrm{ng} / \mathrm{ml}$, measured by ordinary assay) supplemented with $20 \mathrm{ng}$, $50 \mathrm{ng}$, or $100 \mathrm{ng} / \mathrm{ml}$ of $\alpha$ fetoprotein, or $200 \mathrm{ng}$, $400 \mathrm{ng}$, or $600 \mathrm{ng} / \mathrm{ml}$ of ferritin were assayed. As shown in table 3, samples supplemented with $20 \mathrm{ng} / \mathrm{ml}$ of $\alpha$ fetoprotein or $200 \mathrm{ng} / \mathrm{ml}$ of ferritin gave suspicious values, and samples supplemented with higher concentrations of $\alpha$ fetoprotein or ferritin gave positive values.

\section{CLINICAL APPLICATION OF SIMULTANEOUS ASSAY} Healthy subjects

$\alpha$ Fetoprotein and ferritin in 50 sera from healthy Japanese subjects were examined by the ordinary assay procedures using the calibration curves (fig 1 ). In all cases values indicated that the $\alpha$ fetoprotein and ferritin concentrations were below $10 \mathrm{ng} / \mathrm{ml}$ and $200 \mathrm{ng} / \mathrm{ml}$, respectively. These samples were then assayed by the proposed simultaneous assay method. As shown in fig 5, all samples gave absorbancy values at $500 \mathrm{~nm}$ under 0.015 , which was evaluated as negative in this assay.

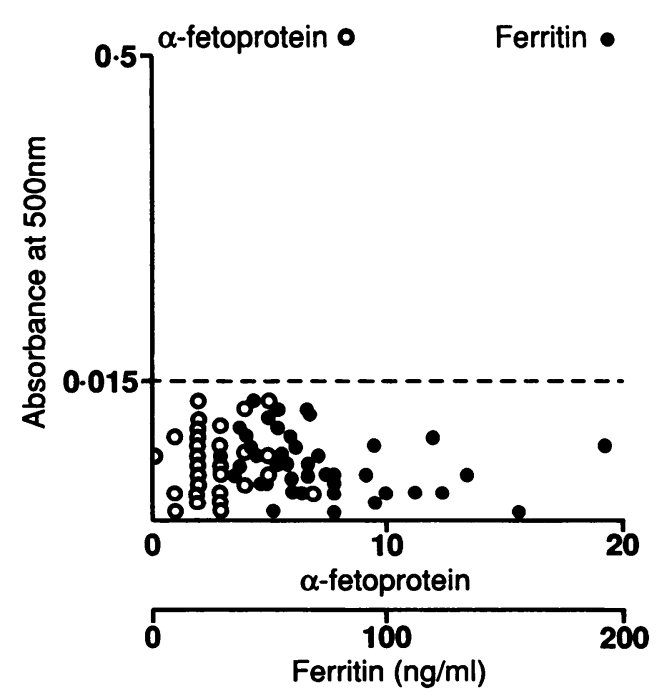

Figure 5 Relation between absorbancies and concentrations of $\alpha$ fetoprotein and ferritin in healthy subjects. 
Figure 6 Detection of abnormal concentrations of $\alpha$ fetoprotein and ferritin in test sera by simultaneous assay. Sera from patients with high $\alpha$ fetoprotein (over $20 \mathrm{ng} / \mathrm{ml}$ ) and high ferritin (over $200 \mathrm{ng} / \mathrm{ml}$ ) concentrations were screened by the simultaneous assay.

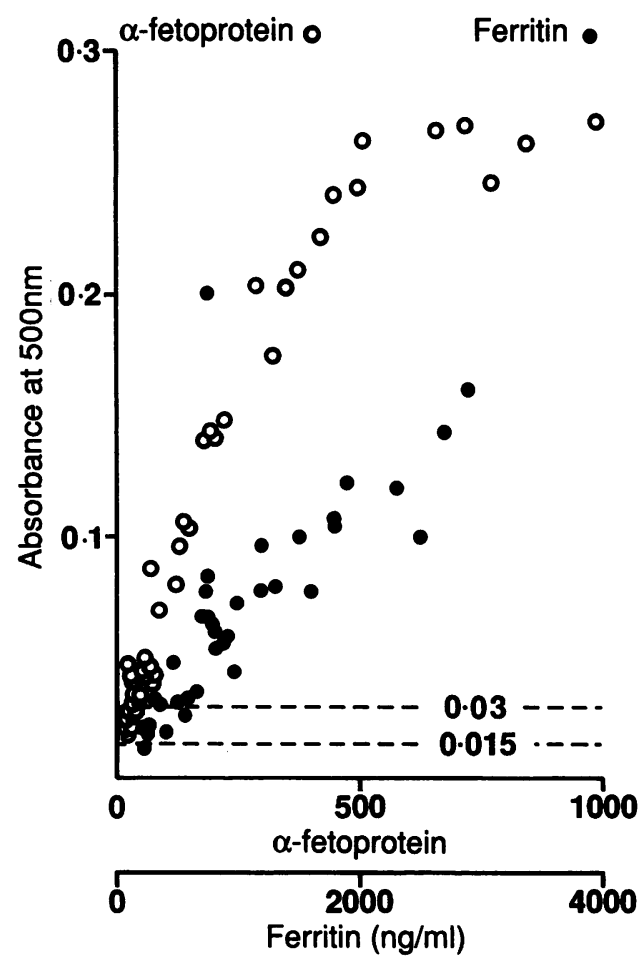

Detection of increased $\alpha$ fetoprotein and ferritin concentrations in serum samples

Fifty serum samples from patients with high $\alpha$ fetoprotein concentrations (over $20 \mathrm{ng} / \mathrm{ml}$ ) and 50 samples with high ferritin concentrations (over $200 \mathrm{ng} / \mathrm{ml}$ ) were assayed by the proposed simultaneous assay method. As shown in fig 6, the absorbancy values of all samples with high $\alpha$ fetoprotein concentrations, and all but one sample $(230 \mathrm{ng} / \mathrm{ml})$ with high ferritin concentrations, gave values above the cutoff point $(0.015)$. Of the samples, $37(74 \%)$ with high $\alpha$ fetoprotein concentrations and $40(80 \%)$ with high ferritin concentrations were evaluated as positive (absorbancy over 0.030 ) and the others as suspicious (absorbancy 0.015-0.030).

\section{Discussion}

Conventional in vitro procedures are used to determine one parameter by one test on one specimen. But tremendous numbers of assays have to be carried out to detect abnormalities in the early stages of disease in individuals in large populations. Several methods have been developed to save time and labour in these mass screenings. One of these is the so called "paired assay system" in which one parameter is measured in mixed blood samples from two subjects. This system has been used in screening for neonatal hypothyroidism ${ }^{4}$ and prolactinoma, which has indicated that a system for determining two parameters in one test would be useful. In this study we used the homogeneous EIA procedure reported previously, based on the finding that in the presence of excess hydrogen peroxide, HRP is not active when conjugated to antibody, but is active in antigenantibody aggregates. ${ }^{56}$

The assay procedure is simple and suitable for use in mass screening. In this study the availability of this method was examined using the two parameters $\alpha$ fetoprotein and ferritin, because homogeneous EIAs for measuring these two parameters separately have been established. The serum $\alpha$ fetoprotein concentration is very low in normal subjects, but increases in diseases such as hepatocellular carcinoma. ${ }^{7}$ Serum ferritin is increased in diseases such as leukaemia and malignant lymphoma. ${ }^{8}$ For practical purposes, however, much more appropriate tumour markers should be selected.

In the proposed simultaneous assay system the cutoff points are set at $20 \mathrm{ng} / \mathrm{ml}$ of $\alpha$ fetoprotein and $200 \mathrm{ng} / \mathrm{ml}$ of ferritin. To obtain similar sensitivities at these concentrations, we added unlabelled anti-ferritin antibody to the EIA system.

The intra- and interassay CVs of the proposed method are acceptable for the purpose of mass screening. As shown in table $1, \alpha$ fetoprotein and ferritin concentrations below these cutoff points were classified as negative or suspicious. In practice, healthy subjects were classified as negative (fig 5 ). Therefore, most sera classified as suspicious were considered to be positive. Thus subjects giving abnormal results were effectively differentiated from normal subjects by the cutoff point (absorbancy: 0.015).

As a tool for mass examination, the present assay system is not limited to the tumour markers, but can be applied to any combination of markers, such as markers of inflammation, neonatal inborn defects, and microbial infection.

1 Mandy WJ, Rivers MM, Nisonoff A. Recombination of nivalent subunits derived from rabbit antibody. $J$ Bio Chem 1961;236:3221-6.

2 Yoshitake S, Yamada Y, Ishikawa E, Masseyeff R. Conjugation of glucose oxidase from aspergillus niger and rabbit antibodies using $\mathrm{N}$-hydroxysuccinimide ester of $\mathbf{N}-(4-$ carboxycyclohexyl-methyl)-maleimide. Eur $J$ Biochem 1979;101:395-9.

3 Nakane PK, Kawaoi A. Peroxidase-labeled antibody. A new method of conjugation. J Histochem Cytochem 1974;22 1084-91.

4 Miyai K, Oura T, Kawashima M, et al. A new method of paired thyrotropin assay as a screening test for neonatal hypothyroidism. J Clin Endocrinol Metab 1978;47: 1028-33.

5 Hoshino N, Hama M, Suzuki R, Kataoka Y, Soe G. A new homogeneous enzyme immunoassay. Its application to homogeneous enzyme immunoassay. Its application to

6 Hoshino N, Nakajima R, Yamazaki I. The effect of polymerization of horseradish peroxidase on the peroxidase activity in the presence of excess $\mathrm{H}_{2} \mathrm{O}_{2}$ : A background for a homogeneous enzyme immunoassay. $J$ Biochem 1987;102:785-91.

7 Abelev GI. Production of embryonal serum $\alpha$-globulin by hepatomas: review of experimental and clinical data. Cancer Res 1968;28:1344-50.

8 Melia WM, Bullock S, Johnson PJ, Williams R. Serum ferritin in hepatocellular carcinoma. Cancer 1983; 51:2112-15. 